\title{
IMPLEMENTASI IZIN PERUBAHAN PENGGUNAAN TANAH (IPPT) LAHAN PERTANIAN PRODUKTIF UNTUK MENJADI LAHAN PERUMAHAN \\ (Studi Kasus Di Kabupaten Tulungagung)
}

\author{
Budi Susanto \\ Fakultas Hukum Universitas Brawijaya \\ Jalanl Veteran, Malang Jawa Timur 65145, Indonesia \\ Budisusant99@gmail.com
}

\begin{abstract}
The need for housing land is increasing as the population grows higher. This forced the developers to use productive agricultural land to develop into residential land. The use of productive agricultural land will affect the decrease of food production, especially rice production. So that anticipative steps needed to the phenomenon of increasing the rate of land conversion that occurred in the community. this research was conducted with qualitative descriptive approach which discussed related to land conversion rate in Tulungagung regency with interview method as data acquisition method. The results will discuss the implementation of permit to license of land use activities in Tulungagung District.
\end{abstract}

Keywords : Land conversion, Implementation, Tulungagung District.

\begin{abstract}
ABSTRAK
Kebutuhan akan lahan perumahan semakin meningkat seiring pertumbuhan penduduk yang semakin tinggi. Hal ini memaksa para pengembang menggunakan lahan pertanian produktif untuk dikembangkan menjadi lahan perumahan,. Penggunaan lahan pertanian produktif akan berimbas pada penurunan produksi pangan khususnya produksi beras. Sehingga diperlukan langkah antisipatif terhadap fenomena peningkatan laju konversi lahan yang terjadi di masyarakat. penelitian ini dilaksanakan dengan pendekatan deskriptif kualitatif yang membahas terkait laju konversi lahan di Kabupaten Tulungagung dengan metode wawancara sebagai metode pemerolehan data. Hasil penelitian akan membahas kegiatan implementasi IPPT di Kabupaten Tulungagung.
\end{abstract}

Kata Kunci : Konversi lahan, Implementasi, Kabupaten Tulungagung 


\section{A. PENDAhuluan}

\section{Latar Belakang Masalah}

Laju konversi lahan pertanian menjadi lahan perumahan dewasa ini terjadi dengan cepat. Tercatat dalam data Direktorat Penatagunaan Tanah Tahun 2010 bahwa luas tanah sawah secara nasional 8.106 .860 ha dan sebagian besar terletak di Pulau Jawa. Namun masalah yang muncul adalah laju konversi lahan di pulau jawa sangatlah tinggi. Tingginya laju konversi lahan di Pulau Jawa disebabkan oleh kemajuan yang pesat terhadap sektorsektor selain pertanian seperti sektor industri dan sosial budaya. sehingga jika hal ini dibiarkan oleh pemerintah maka ketahanan pangan nasional akan semakin melemah mengingat Pulau Jawa sebagai supplier beras nasional.

Fenomena peningkatan laju konversi lahan pertanian menjadi lahan perumahan perlu dikaji lebih mendalam. Pengkajian yang perlu dilakukan terkait implementasi dari IPPT yang dikeluarkan pemerintah yang berhubungan dengan penyusunan Rancangan Tata Ruang Wilayah (RTRW) khususnya pemerintah DATI II yang telah diatur dalam perundang undangan. Dalam posisi hukum, lahan pertanian memiliki posisi yang kuat karena didukung dan dikuatkan oleh beberapa peraturan perundang undangan. Sehingga pengkajian mendalam perlu dilakukan terkait implementasi IPPT oleh Pemerintah DATI II baik melalui sudut pandang hukum maupun sudut pandang realitas di lapangan.

Penelitian ini besifat deskriptif yakni memberikan informasi dan gambaran mengenai Implementasi Izin Perubahan Penggunaan Tanah. Data yang diperoleh dengan metode wawancara kepada pihak-pihak yang berkaitan langsung yang berwenang. Sehingga bisa menjelaskan faktor yang mempengaruhi pelaksanaan IPPT dilapangan serta memberikan gambaran yang jelas terhadap situasi implementasi IPPT dalam kaitannya konversi lahan pertanian di mata hukum. 
Kegiatan penelitian dilaksanakan di Kabupaten Tulungagung secara purposive sampling. Pemilihan lokasi ini dikarenakan Kabupaten Tulungagung memiliki memiliki wilayah lahan persawahan yang luas baik itu sawah irigasi teknis maupun semi teknis. Selain itu wilayah Kabupaten Tulungagung sangat potensial dalam hal konversi lahan pertanian ke lahan perumahan dikarenakan pertumbuhan diberbagai sektor seperti demografi, industry, pariwisata dan sektor lainnya yang tinggi. Oleh karena itu Kabupaten Tulungagung dapat dijadikan sebagai lokasi penelitian yang memiliki data sesuai dengan yang dibutuhkan oleh peneliti.

\section{Rumusan Masalah}

Faktor apa yang mempengaruhi implementasi IPPT dalam kaitannya konversi lahan pertanian di mata hukum.

\section{Tujuan Penelitian}

Untuk mengkaji secara mendalam faktor apa yang mempengaruhi implementasi IPPT dalam kaitannya konversi lahan pertanian di mata hukum.

\section{B. PEMBAHASAN}

\section{Implementasi IPPT Ditinjau dari Aspek Hukum}

Sesuai dengan Undang-undang Nomor 26 Tahun 2007 menerangkan bahwa dalam penyusunan RTRW yang bersinggungan langsung dengan IPPT perlu memperhatikan faktor keterpaduan antar sektor keselarasan antar daerah, keberlanjutan pembangunan, keterbukaan, kebersamaan; perlindungan hukum; keadilan dan akuntabilitas. Dalam pelaksanaannya pemerintah DATI II sebagai pelaksana Undang-undang ini perlu memperhatikan aspek-aspek tersebut guna mencapai pembangunan yang seimbang. Namun implementasi di lapangan menunjukkan hal yang berbeda. Dalam pelaksanan pembangunan tidak berpihak kepada sektor pertanian sehingga sector vital ini dikesampingkan bahkan dilupakan. 
Implementasi IPPT diatur dalam perkaba BPN Nomor 02 Tahun 2001 Pasal 3 ayat (3) dalam kaitannya penyusunan RTRW perlu memperhatikan asas keberlanjutan. Dalam asas ini dijelaskan tentang penyusunan RTRW perlu memikirkan dampak jangka panjang dalam kaitannya menjaga keberlangsungan lahan pertanian untuk generasi mendatang. Hal ini menunjukan posisi lahan pertanian sangatlah di perhatikan dalam penyusunan RTRW sehingga peraturan ini memberikan penguatan terhadap posisi lahan pertanian itu sendiri.

Selain itu dalam Perda Kabupaten Tulungagung nomor II/2012 tentang tata wilayah Kabupaten Tulungagung tahun 2012-2032 pada bab VII pasal 55 tentang pembukaan dan pengembangan potensi kawasan setrategis dan pertanian tanaman pangan. Serta penanganan dan pengelolaan kawasan DAS, anak sungai, sumber daya alam berlandaskan kelestarian lingkungan. Perlu diperhatikan guna menjaga kelestariannya. Sehingga dari peraturan ini menunjukkan adanya kekuatan hukum yang dimiliki oleh lahan pertanian.

Selain peraturan-peraturan diatas terdapat juga peraturan lain yang mengenai larangan alih fungsi lahan pertanian dan bersinggungan langsung dengan IPPT antara lain :

a. Keputusan Presiden Nomor 53 Tahun 1989 menjelaskan bahwa kawasan industry tidak menggunakan sawah dan sawah pertanian yang subur lainnya dan peraturan ini juga mencakup sektor perumahan, jasa dan lain sebagainya

b. Surat Menteri Negara Perencanaan Pembangunan Nasional/Ketua Bappenas Kepada Menteri Negara Agraria / Kepala Badan Pertanahan Nasional Nomor 5334/MK/9/1994 dan Nomor 5335/MK/9/1994 tanggal 29 september 1994 tentang perubahan penggunaan tanah non pertanian dan penyusunan RTRW Pemerintah Dati II;. Peraturan peraturan diatas memberikan perlindungan terhadap keberadaan lahan pertanian yang ada. 


\section{Kelemahan Sistem Perundang-Undangan Yang Mengatur Konversi Lahan Pertanian}

Perundang-undangan terkait IPPT yang telah disusun dan disahkan pemerintah memberikan posisi hukum yang jelas terhadap lahan pertanian. Posisi tersebut telah diakui oleh hukum dengan syarat-syarat yang telah tercantum didalamnya. Dalam peraturan hukum yang telah dibuat memberikan gambaran yang jelas terkait karakteristik lahan pertanian produktif yang terikat secara hukum. Oleh sebab itu adanya peraturan hukum yang telah dibuat merupakan suatu pengakuan pemerintah terhadap posisi hukum lahan pertanian.

Melihat adanya syarat-syarat lahan pertanian yang diatur dalam peraturan perundang-undangan memberikan suatu karakteristik bagi lahan pertanian untuk mendapatkan pengakuan hukum. Pengakuan ini didapat dari kesesuaian karakter lahan sawah dengan isi dari peraturan hukum tersebut. hal ini memberikan celah bagi pengembang untuk menghilangkan kekuatan hukum lahan sawah di mata hukum..para pengembang memiliki beberapa perilaku yang bertujuan menghilangkan karateristik persawahan yang telah ada dalam perundang undangan. Sehingga kekuatan hukum yang dimiliki oleh lahan persawahan hilang dan konversi lahan pertanian pun terjadi.

Kegiatan penghapusan posisi hukum bagi lahan pertanian sering terjadi. Penghapusan ini bertujuan untuk menghilangkan ikatan hukum terhadap objek hukum dalam hal ini adalah lahan pertanian. Dalam peraturan-peraturan yang mengikat lahan pertanian sudah tertulis secara jelas karakteristik yang harus dipenuhi oleh lahan pertanian supaya mendapatkan pengakuan hukum. Sehinga jika terjadi ketidak sesuaian antara apa yang telah tertulis dalam hukum dan keadaan nyata objek hukum maka peraturan hukum yang mengikat tersebut hilang. Oleh karena itu pihak-pihak yang memiliki kepentingan untuk melakukan konversi lahan akan berusaha menghilangkan karakteristik objek hukum agar terlepas dari ikatan hukum. 
Adapun beberapa kegiatan yang sering terjadi kepada lahan pertanian subur agar kehilangan posisi hukumnya antara lain :

a. Menutup saluran irigasi supaya sawah mengering.

b. Mengeringkan lahan persawahan supaya berubah menjadi tegalan.

c. Merubah sistem ekologi lahan pertanian agar kehilangan kesuburannya.

d. Menimbun lahan pertanian dengan material batuan atau tanah liat sehingga tidak dapat ditanami.

e. Mengganggu ekosistem persawahan sehingga sawah kehilangan produktifitasnya

f. Menghentikan siklus pengolahan tanah pertanian sehingga lahan tersebut menjadi lahan tidur dan dipenuhi semak belukar.

Berdasarkan hal-hal tersebut yang menjadi mula perubahan karakteristik objek hukum dalam hal ini tanah pertanian adalah dengan cara mengalihkan hak tanah atas dari pihak satu (petani) kepada pihak kedua (pengembang/pemilik modal). Sehingga hak atas tanah telah beralih tangan dan pihak kedua secara leluasa mengolah dan mengatur lahan pertanian sesuai dengan kehendaknya.

\section{Peraturan Perundang-Undangan Yang Membatasi Konversi Lahan Pertanian}

Adapun peraturan yang membatasi dan melindungi lahan pertanian dari kegiatan konversi pemanfaatan lahan antara lain :

a. Undang-undang Nomor 24 Tahun 1992 tentang keberlangsungan sawah irigasi teknis sebagai budidaya pangan berkelanjutan

b. SE MNA/KBPN 410-1851 tentang pelarangan konversi lahan pertanian/sawah irigasi teknis (SIT) untuk kepentingan apapun

c. SEMN/KBPN 410-2261/1994 tentang pelarangan penerbitan IPPT untuk konversi lahan pertanian/SIT 
d. SE/KBAPPENAS 5334/MK/9/1994 tentang peralangan konversi lahan sawah irigasi teknik untuk keperluan non pertanian.

e. SE MNA/KBPN 5335/MK/1994 tentang pelarangan konversi sawah irigasi teknis dalam penyusunan RTRW tingkat pemerintahan DATI I dan DATI II.

f. SEMNA/KBPN5417/MK/10/1994 mengatur tentang pelarangan penggunaan lahan sawah irigasi teknis untuk diperuntukkan sebagai perumahan.

g. SE MENDAGRI 474/4263/SJ/1994 yang mengatur tentang keberadaan tanah pertanian dalam hal ini sawah irigasi teknik untuk mendukung swasembada pangan.

h. SE MNA/KBPN 460-1594/1996 tentang pencegahan konversi sawah irigasi teknik untuk sector lainnya dan himbauan menjaga ekosistem sawah.

\section{Faktor Penyebab Konversi Lahan Pertanian}

Adapun faktor dari penyebab konversi lahan antara lain yaitu, faktor kependudukan, perkembangan sektor non pertanian, faktor ekonomi, factor sosial budaya, degradasi/penurunan kualitas lingkungan, otonomi daerah, myopic ( kebijakan untuk mengejar keuntungan jangka pendek) serta faktor lemahnya sistem perundag-undangan.

Selain itu menurut Sidipurwanty, terdapat juga faktor lain yang menyebabkan alih fungsi tanah pertanian yaitu, faktor internal yang meliputi sisten waris dalam keluarga, luas lahan yang sempit dan memiliki keuntungan kecil jika ditanami, desakan ekonomi serta faktor eksternal yang meliputi regulasi pemerintah dan redist.ribusi lahan pertanian. 


\section{PENUTUP}

\section{Kesimpulan}

Berdasarkan penjelasan di atas, maka dapat disimpulkan bahwa implementasi tujuan peruntukan penggunaan tanah (IPPT) tanah pertanian produktif menjadi non produktif di Kabupaten Tulungagung sangat tergantung pada seberapa jauh semua pihak untuk memahami kebijakan-kebijakan penataan ruang itu sendiri serta kesadaran dan dukungan semua elemen baik pemerintah, swasta dan masyarakat. Semakin baik pemahaman dan kesadaran semua pihak pada aturan akhir multifungsi lahan pertanian produktif akan selalu efektif. Implementasi kebijakan pengendalian alih fungsi lahan pertanian ke non pertanian sehingga akan dapat menjadikan serta mempertahankan kelestaraian lahan pertanian.

Adapun faktor-faktor yang menyebabkan pemberian ijin peruntukan penggunaan tanah (IPPT) tanah pertanian produktif menjadi non produktif di kabupaten tulungagung adalah: faktor kependudukan, ekonomi, sosial budaya dan kebutuhan lahan non pertanian kebijakan pemerintah yang menjadi penyebab alih fungsi sulit dikendalikan. 


\section{DAFTAR PUSTAKA}

\section{A. Peraturan Perundang-undangan}

Undang-Undang Nomor 24 Tahun 1992 tentang Penataan Ruang.

Undang-Undang Nomor 26 Tahun 2007 tentang Penataan Ruang.

Keputusan Presiden Nomor 53 Tahun 1989 tentang Kawasan Industri.

Peraturan Daerah Kabupaten Tulungagung Nomor 11 Tahun 2012 tentang Rencana Tata Ruang Kabupaten.

Peraturan Kepala Badan Pertanahan Nasional Republik Indonesia Nomor 2 Tahun 2011 tentang Pedoman Pertimbangan Teknis Pertanahan Dalam Penerbitan Izin Lokasi, Penetapan Lokasi dan Izin Perubahan Pembangunan Tanah.

Surat Edaran Menteri Dalam Negeri No. 474/4263/SJ/1994 Tentang mempertahankan Sawah Beririgasi Teknis Untuk Mendukung Swasembada Pangan

Surat Edaran Menteri Negara Agraria /KBPN 5335/MK/1994 tentang Penyusunan Rencana $\mathrm{T}$ ata Ruang Wilayah tingkat Kabupaten/Kota.

Surat Edaran Menteri Negara Agraria/KBPN 410-1851 tentang Pencegahan Penggunaan Tanah Sawah Beririgasi Teknis Untuk Penggunaan Non Pertanian Melalui Penyusunan RTR

Surat Edaran Menteri Negara Agraria/KBPN 410-2261/1994 tentang Aturan Alih Fungsi Lahan Pertanian Subur

Surat Edaran Menteri Negara Agraria/KBPN 460-1594/1996 Tentang Pencegahan Penggunaan Tanah Sawah Beririgasi Teknis Untuk Penggunaan Non Pertanian

Surat Edaran Menteri Negara Agraria/KBPN5417/MK/10/1994 tentang Efisiensi Pemanfaatan Lahan Bagi Pembangunan Perumahan.

Surat Edaran/KBAPPENAS 5334/MK/9/1994 tentang Perubahan Penggunaan Tanah Sawah Beririgasi Teknis untuk Penggunaan Tanah Non Pertanian. 


\section{B. Literatur}

Jhamtani, Hira. 2008. Lumbung Pangan, Menata Ulang Kebijakan Pangan Yogyakarta: INSIST Press.

Sidipurwanty, Eliana. 2014. Penelitian Dinamika Dan Peluang Pengendalian Alih Fungsi Tanah Sawah. Jakarta : Puslitbang Kementerian Agrarian Dan Tata Ruang/Badan Pertanahan Nasional

Soemitro, Ronny H. 1985 Metode Penelitian Hukum dan Jurimetri, Jakarta: Ghalia Indonesia 